\title{
Perception of organizational justice of the workers of a public university in Mexico hired under the outsourcing modality
}

\section{Percepción de justicia organizacional de los trabajadores de una universidad pública en México contratados bajo la modalidad de outsourcing}

HERNÁNDEZ-GOVEA, Luis Manuel†, MAY-GUILLERMO, Erika Guadalupe*, DE LA CRUZMAY, Samuel and SALVADOR-GARCÍA, Yazmin Denisse

Universidad Juárez Autónoma de Tabasco

Instituto Tecnológico Superior de la Región Sierra

Universidad Intercultural del Estado de Tabasco

ID $1^{\text {st }}$ Author: Luis Manuel, Hernández-Govea / ORC ID: 0000-0001-6371-8135, CVU CONACYT ID: 1095368

ID $1^{\text {st }}$ Coauthor: Erika Guadalupe, May-Guillermo / ORC ID: 0000-0001-5403-9849, Researcher ID Thomson: W-43932019, CVU CONACYT ID: 366439

ID $2^{\text {nd }}$ Coauthor: Samuel, De La Cruz-May / ORC ID: 0000-0001-9180-6349, Researcher ID Thomson: ABD-3123-2020, CVU CONACYT ID: 862273

ID $3^{\text {rd }}$ Coauthor: Yazmin Denisse, Salvador-Garcia / ORC ID: 0000-0003-3047-7558, Researcher ID Thomson: S-75862018, CVU CONACYT ID: 824554

DOI: $10.35429 / J H R T .2020 .18 .6 .6 .17$

Received: June 30, 2020; Accepted: December 20, 2020

\section{Resumen}

A descriptive, quantitative study is presented, with a nonexperimental and cross-sectional design, carried out with the objective of describing the level of organizational justice perceived by the workers of a public university, hired under the outsourcing modality and its relationship with some demographic variables. The data collection technique was the survey and the instrument used to measure perceived organizational justice was the Niehoff and Moorman scale (1993) adapted by Patlán et al. (2014) for use with the Mexican population. The sample consisted of 16 workers from a public Higher Education Institution (IES) located in the state of Tabasco, Mexico. The study findings show that workers perceive average levels of organizational justice, predominantly interactional justice, followed by procedural justice and later distributive justice. In turn, it was identified that the academic degree was the only differentiating demographic variable with respect to the levels of organizational justice perceived by the population studied. The main contribution of the study was to consider as a population a segment of workers who, due to the characteristics of their hiring modality, have psychosocial implications that may affect their organizational performance.

Organizational Justice, Education Workers, Outsourcing

\section{Resumen}

Se presenta un estudio de tipo descriptivo, cuantitativo, con diseño no experimental y transversal, realizado con el objetivo de describir el nivel de justicia organizacional percibida por los trabajadores de una universidad pública, contratados bajo la modalidad de outsourcing y su relación con algunas variables demográficas. La técnica de recopilación de datos fue la encuesta y el instrumento utilizado para medir la justicia organizacional percibida fue la escala de Niehoff y Moorman (1993) adaptada por Patlán et al. (2014) para su uso con población mexicana. La muestra estuvo integrada por 16 trabajadores de una Institución de Educación Superior (IES) pública ubicada en el estado de Tabasco, México. Los hallazgos del estudio muestran que los trabajadores perciben niveles medios de justicia organizacional, predominando la justicia interaccional, seguida de la justicia de procedimientos y posteriormente la justicia distributiva. A su vez, se identificó que el grado académico fue la única variable demográfica diferenciadora respecto a los niveles de justicia organizacional percibida por la población estudiada. La principal contribución del estudio fue considerar como población a un segmento de trabajadores que por las características de su modalidad de contratación presentan implicaciones psicosociales que pueden incidir en su desempeño organizacional.

Justicia Organizacional, Trabajadores de la educación, Outsourcing

Citation: HERNÁNDEZ-GOVEA, Luis Manuel, MAY-GUILLERMO, Erika Guadalupe, DE LA CRUZ-MAY, Samuel and SALVADOR-GARCÍA, Yazmin Denisse. Perception of organizational justice of the workers of a public university in Mexico hired under the outsourcing modality. Journal of Human Resources Training. 2020, 6-18: 6-17

*Correspondence to Author (saoridenise@ hotmail.com)

$\dagger$ Researcher contributing first Author 


\section{Introduction}

The economic terms, with the passage of time, have frequently incurred extremely important changes regarding the needs that arise. That is why, if we talk about significant changes over time, there is a specific issue that has undoubtedly had such variations, such as work, since individuals and their needs have changed as The years go by.

The work, since biblical times, had different appreciations in relation to the political, social and cultural, but above all in the economic activities that led to the human being, creating and reproducing his existence through nature, taking parts of it consecutively to survive. However, despite the fact that individuals were owners of their own work, they were not rewarded in favor of it, but many of them were despised for the type of work they did or even many were slaves, who did not see the reward for their effort (Albanesi, 2015).

However, over time humans developed a system of cooperation at work, providing a reward in the working day. Even, by the end of the 18th century in Europe, the notion of work already had many scopes and rights of which in previous years they did not have, one of them is thanks to the changes in economic perceptions that the Theory of Value represented- Adam Smith's work (Smith, 1976). Undoubtedly, its approach, forged several guidelines that served for labor rights that were later used for the benefit of the working class (Albanesi, 2015).

Even Sztulwark and Míguez (2012) mention that, with the advent of industrial capitalism, the process of subordination of the working class was emphasized, since, thanks to this, importance began to be given to the effort of the working class, to guarantee security and the salary regime, granting them subsequent rights to sell their workforce. This was further reinforced with the consolidation of capitalist relations, since wage labor transformed one of its bases. In addition to this, technological advances in recent decades have allowed companies to further consolidate their workforce to obtain diverse and gratifying results (Sztulwark \& Míguez, 2012).

\section{Theoretical foundation}

\section{Organizational Justice}

In the search for salary improvements, the process of organizational justice in organizations has been changing as the needs of human beings are transformed, this always looking for improvements in a wide panorama of their needs (Quezada-Abad , 2017). Speaking in terms of job performance, labor ties or labor rights, they have opened various fields in favor of the satisfaction of various needs that a worker needs in order to feel complete and satisfied in their work environment (Patlán, 2016).

In addition to this, and emphasizing in these terms, a special one arises, which, without a doubt, brings great expectations regarding the feeling of an employee in his work environment complying with certain conditions, which is called Organizational Justice, since it is related to concepts such as equity and justice (MartínezTur et al., 2014).

According to Omar (2006) the term Organizational Justice refers to how the worker perceives the work environment, that is, what is fair and unfair within the organization to which a person belongs, referring to the treatment of them by organizational management.

In general terms, according to PatlánPérez and Martínez (2012), research related to the concept of organizational justice has been divided into at least two very interesting axes; In this sense, Greenberg (1993) proposed a division to study this phenomenon dividing it into two large segments: 1) distributive and procedural justice, and 2) structural justice, which refer to the perception of the worker, if his treatment is fair in the various areas of performance of their work activities, and therefore, if their salary is also fair because of what they do.

In the same way, Colquitt (2001) gives it a similar approach, dividing the study of this issue into four approaches: distributive, procedural, interpersonal and informational, giving rise to the so-called interpersonal and informational justice. According to Omar (2018), the first includes social sensitivity, which is how the worker perceives the dignified and respectful treatment of certain decisions that the organization makes. 
In the same context the second approach, it is perceived if the explanation or justification of the organization stops or calms the negative reactions of the worker before diverse behaviors of injustice. Both authors agree that the sensitive perception of the worker has a lot to do with their progress and results obtained in their field of work (Castillo \& Fernandez, 2017).

Organizational Justice, although it is a concept studied mostly by the field of psychology, has a direct impact on the economy of many companies since, without a doubt, individuals react consistently in their productivity based on their physical and emotional state (Kozlowski , 2012) so that equity and inequity can be considered internal factors to take into account when wanting to improve worker conditions and their field of action (Peña-Ochoa \& Durán, 2016).

\section{Factors that influence Organizational Justice}

\section{Work stress}

The pressures of life, such as family, economic and social problems, can generate concerns that, without a doubt, affect the worker and his productivity directly, since stress exceeds the person's resistance capacity (Omar, 2006 ).

In addition to this, García and Forero (2014) add that job stress arises when work pressures exceed the worker's ability to cope, which generate the physical and mental vulnerability of the person, resulting in absenteeism, job rotation or layoffs, hence these effects are seen in the economy of a country, reflected in the business losses suffered annually due to lack of attention to stress (Quezada-Abad, 2017).

This is a phenomenon that has been happening repeatedly in all the economies of the world, which is why adequate instruments have been developed to explore the sources of this type of stress, such as the Occupational Stress Index (ISO) (Omar, 2004). Which is made up of five variants: job satisfaction, psychological well-being, physical well-being, sources of stress and coping strategies (Marsollier \& Aparicio, 2011).

\section{Organizational Commitment}

Cernas et al. (2018) mention that organizational commitment is the most important work attitude in the world, since it promotes planned behavior and especially interaction and social exchange, resulting in a positive environment in their work environment focused on behaviors commitment that exist between the worker and the company (Cernas et al., 2018). This also operates vice versa, since, in the absence of commitment from all its actors, there are negative results in all areas (Claure \& Böhrt, 2015).

\section{Work satisfaction}

For there to be an effective relationship between all the entities that work in an organization, there must be a relationship between the organization and its workers that can always satisfy the changing needs of both parties (Sánchez \& García, 2017). Job satisfaction is directly related to the knowledge that the person has within the organization, transforming into perception and culminating in an emotional component that defines the person's way of acting (Charaja \& Mamani, 2014).

Chiang et al. (2007) conceptualize job satisfaction as an attitude or set of attitudes that are developed by the person towards her work, especially towards their general and particular situation in it. Therefore, as a result of these two concepts, we can see that job satisfaction should not be considered as a casual factor within organizations, since the worker's level of performance will depend on how much he likes his job and on factors such as development, safety, hygiene and incentives that exist to carry out their functions (Cernas et al., 2016).

\section{Organizational Trust}

Lockward and Ailín (2011) mention that in the same way that job satisfaction generates calm in the worker, trust in the organization creates stability in the behavior of human capital, since this feeling of stability can serve as a basis for that they develop relationships based on commitment, creating greater involvement in the organization (Quezada-Abad, 2017). 
On the contrary, it produces injustice, which generates intellectual and emotional indignation causing lack of trust and resentment to the organization, so this part must be taken care of by the organization so as not to promote low productivity due to factors that can be avoided (Lockward \& Ailín, 2011; QuezadaAbad, 2017).

\section{Types of Organizational Justice}

\section{Distributive Justice}

Rodrigues et al. (2009) mention that organizational justice refers to the perceptions of justice that workers have of what is awarded to them, whether they are rewards or punishments of the organization. However, in the organizational field, it is emphasized that this is directly related to what workers receive from managers, so that, in this field, it is the workers who evaluate their performance based on what they receive ( Zúñiga-Fajuri, 2011). Therefore, distributive justice is influenced by factors such as equality (same opportunities for all), need (distribution according to what the person needs) and equity (it is based on what the worker contributes and what he obtains in reference to what others contribute and obtain) (Dieterlen, 2014).

\section{Procedural justice}

According to Patlán et al. (2014) this type of justice is based on the perception that develops in human capital about equity in the procedures established for the allocation of resources, benefits and decisions of workers, that is, it focuses on how the worker perceives the elements that are provided to him to carry out his work, without altering his ethics and self-love (Mladinic \& Isla, 2011).

According to Patlán et al. (2014) the elements of procedural fairness are: Consistency (procedures and rules must be applied to all employees); Free from bias (non-discrimination or inappropriate treatment by the organization or company of the worker); Accuracy (all information must be based on facts and precise and exact information, and Ethics, which must be based on standards of conduct that must not be violated in the workplace (Patlán et al., 2014; Ríos \& Carranza, 2019).

\section{Interactional Justice}

Cropanzano et al. (2007) mention that interactional justice focuses on the suitability or fair treatment that workers receive from their superiors and that it includes two important components for its operation: Interpersonal justice, which refers to treating an employee with dignity, courtesy and respect from their superiors and informational justice, which leads to sharing relevant information with employees (Rodríguez et al., 2014).

\section{Measurement Instruments Organizational Justice}

for

As a result of the years, authors such as Rodríguez-Montalbán et al. (2015) have addressed the issue, and have used different ways to measure how satisfied a person is with their work, since as has been analyzed in this context, the needs of the company or organization, as well as human capital, are always constantly changing, so their satisfaction with the environment in which they work is also.

Patlán et al. (2014) emphasize that there are several authors who argue that the measurement for this topic should be carried out with a single item for each of the dimensions of organizational justice: distributive, procedural and interactional (Jordan \& Turner, 2008).

Similarly, other authors such as Greenberg (1993) have developed other measurement methods, such as the two-factor scale; Regarding Niehoff and Moorman (1993) in their analysis they present a scale of three factors and Colquitt (2001) presents up to four factors.

For their part, Rahim et al. (2000) designed an index of organizational justice to measure distributive, procedural and interactional justice (Patlán et al., 2014). Table 1 presents a comparison based on the instruments and models for measuring organizational justice. 


\begin{tabular}{|c|c|c|c|}
\hline Scale & Factors & Author & Country \\
\hline $\begin{array}{l}\text { Two- } \\
\text { dimensional } \\
\text { model of } \\
\text { organizational } \\
\text { justice }\end{array}$ & $\begin{array}{l}\text { Distributive } \\
\text { and procedural } \\
\text { justice } \\
\text { Structural and } \\
\text { social justice }\end{array}$ & $\begin{array}{l}\text { Greenberg } \\
(1993)\end{array}$ & U.S \\
\hline $\begin{array}{l}\text { Three- } \\
\text { dimensional } \\
\text { model of } \\
\text { organizational } \\
\text { justice }\end{array}$ & $\begin{array}{l}\text { Distributive } \\
\text { justice } \\
(5 \text { questions; } \\
\alpha>.90) \text {. } \\
\text { Procedural } \\
\text { justice } \\
(6 \text { questions; } \\
\alpha>.90) \text {. } \\
\text { Interactional } \\
\text { justice } \\
(9 \text { questions; } \\
\alpha>.90)\end{array}$ & $\begin{array}{l}\text { Niehoff y } \\
\text { Moorman } \\
\text { (1993) }\end{array}$ & U.S \\
\hline $\begin{array}{l}\text { Organizational } \\
\text { justice index }\end{array}$ & 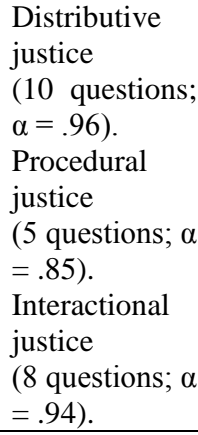 & $\begin{array}{l}\text { Rahim, } \\
\text { Magner y } \\
\text { Shapiro } \\
(2000)\end{array}$ & U.S \\
\hline $\begin{array}{l}\text { Four- } \\
\text { dimensional } \\
\text { model of } \\
\text { organizational } \\
\text { justice }\end{array}$ & $\begin{array}{l}\text { Distributive } \\
\text { justice } \\
\text { (4 questions; } \alpha \\
=.84 \text { ). } \\
\text { Procedural } \\
\text { justice } \\
\text { ( } 7 \text { questions; } \alpha \\
=.84 \text { ). } \\
\text { Interpersonal } \\
\text { justice } \\
\text { (4 questions; } \alpha \\
=.96 \text { ). } \\
\text { Informational } \\
\text { Justice } \\
(5 \text { questions; } \alpha \\
=.90) \text {. }\end{array}$ & $\begin{array}{l}\text { Colquitt } \\
\text { (2001) }\end{array}$ & U.S \\
\hline $\begin{array}{l}\text { Scale of one } \\
\text { item per factor }\end{array}$ & $\begin{array}{l}\text { Distributive } \\
\text { justice } \\
(1 \text { item; } \alpha= \\
.83) . \\
\text { Procedural } \\
\text { justice } \\
(1 \text { item; } \alpha= \\
.54) \text {. } \\
\text { Interactional } \\
\text { justice } \\
(1 \text { item; } \alpha= \\
.89)\end{array}$ & $\begin{array}{l}\text { Jordan } \\
\text { Turner } \\
(2008)\end{array}$ & U.S \\
\hline
\end{tabular}

Table 1 Instruments and models for measuring organizational justice.

Adaptation of Patlán et al. (2014)

\section{Relationship between organizational justice and job performance}

In Latin America, especially in Mexico and the Southeast of the country, there is very limited information regarding these issues, which are currently of great social and economic interest.
However, it has been possible to analyze information on the subject from studies in other countries, widely identifying the effects that organizational justice causes in economic entities, especially the effects of human behavior on productivity (Peña-Ochoa \& Durán, 2016).

Ríos and Carranza (2019) refer to the role that justice plays in the organization and the way in which it is applied to workers, which guarantees their effectiveness, which, together with satisfaction experiences that workers experience derived from finding that the organization for which they work meets their expectations, is not only an image indicator but also a commitment to it (Peña-Ochoa \& Durán, 2016). For this reason, it is necessary to mention that while job performance is intrinsically linked to organizational justice, the more justice flows, the greater the performance and commitment that result favorably in productivity ( $\mathrm{Al}-\mathrm{Zu}$ 'bi, 2010).

\section{Importance of Organizational Justice}

Organizational justice as mentioned by Tziner et al. (2015) is undoubtedly an element that must be studied and applied in any existing organization, call it a company or a public body, since the set of decisions that these large economic entities make every day, generates feelings, emotions, behaviors and results positive or negative towards their working capital, towards their superiors and even towards the organization itself (Fox et al., 2001).

An example of this is the research carried out by Rubio (2018) in a private university in Armenia in order to know the relationship between organizational commitment and organizational justice. Within their results, they found a moderate and low positive correlation between organizational justice factors and degrees or dimensions of commitment.

In accordance with the results obtained by Rubio (2018), we can undoubtedly underline that organizational justice has the potential to create great benefits for organizations and their workers; Among them, the existence of greater trust and commitment, which produces an evident improvement in the work performance of human capital, as well as improvement reflected in customer satisfaction, creating a better work environment that will contribute to obtaining results that impact in productivity for the organization (Patlán et al., 2014).

HERNÁNDEZ-GOVEA, Luis Manuel, MAY-GUILLERMO, Erika Guadalupe, DE LA CRUZ-MAY, Samuel and SALVADOR-GARCÍA, Yazmin Denisse. Perception of organizational justice of the workers of a public university in Mexico hired under the outsourcing modality. Journal of Human Resources Training. 2020 
For their part, Cernas et al. (2018) mention that when workers perceive that they are treated fairly, not only productive improvements are generated, but it also causes positive attitudes towards work, towards superiors and towards the organization itself; This means that factors such as work stress are minimal, and leads to affective states such as anxiety, decreasing in human capital, achieving, as mentioned, surprising results in organizations that take it into account as part of work wellbeing ( Cernas et al., 2018).

\section{Hiring by outsourcing}

Derived from the socioeconomic changes generated by globalization, organizations have chosen to modify their structures, in order to reduce costs and increase productivity through more flexible contracting mechanisms such as outsourcing, which they consider a strategy to remain in the market (Vesga, 2011).

According to Bustamante and Bermúdez (2010) outsourcing is an Anglophone term that comes from the word out and source, that is, the place where something can be obtained. In this sense, outsourcing consists of delegating certain activities or processes of a company to a third party so that he can manage them, seeking to obtain greater effectiveness.

According to López (2010), outsourcing is a strategy that companies use to separate themselves from legal commitments, increase employment flexibility and reduce production costs. However, the rights of workers are not fulfilled: they do not have defined contracts, they work flexible hours, they do not create seniority and they are hired by specialized companies other than the one where they provide their services.

In this regard, Echaiz (2008) argues that the informal economy is the precursor of flexible specialization and, in turn, favors the emergence of outsourcing in small companies in the agricultural sector in Italy.

In Mexico, this form of contracting became popular as of 1960, initially being used in auxiliary service companies such as cleaning and surveillance and gradually encompassing other functions such as recruitment, selection of personnel and contexts such as education (López, 2010).

\section{Implications of outsourcing contracting}

According to Vesga (2011), there is theoretical and empirical evidence on the psychological implications that contemporary forms of contracting, such as outsourcing, generate in workers, such as the affectation towards psychosocial aspects.

In this regard, Bustamante and Bermúdez (2010) point out that these forms of subcontracting can generate positive implications in the motivation of subcontracted workers, as well as negative implications through feelings of discomfort and demotivation due to working conditions that have been deteriorated.

In this sense, Manriquez, Rendón, Sánchez-Fernández and Guerra (2017) point out that generally, organizations that choose to outsource personnel only bear in mind the costs that they reduce by avoiding the workload; However, they do not analyze the hidden costs of this, such as low levels of organizational commitment and other perceptions at work attitudes.

\section{Problem Statement}

Human capital is one of the essential elements for organizational effectiveness. Therefore, the perception that employees have in relation to the way they are valued in an organization is essential for the performance of their activities.

In this sense, the perception of experiencing a work environment where organizational justice prevails contributes to the generation of positive attitudes and feelings towards the organization. However, labor hiring through the outsourcing modality has become a common practice in public and private organizations to avoid the workload, affecting work attitudes (Manriquez et al., 2017).

Currently, little is known about the perceptions of Organizational Justice that education workers who work under the outsourcing contracting scheme have and the relationship that certain demographic variables have in said perceptions. 
In this sense, unfavorable perceptions of organizational justice can lead to attitudes and feelings being assumed against the objectives of the organization in the event that workers perceive that they are being treated unfairly due to the characteristics of the low modality. which are hired. Given this, the following research objectives and hypotheses are presented.

\section{General purpose}

Describe the level of organizational justice perceived by the workers of a public university, hired under the outsourcing modality and its relationship with some demographic variables.

\section{Specific objectives}

- Identify the level of organizational justice perceived by the workers of a public university, hired under the outsourcing modality.

- Analyze the relationship between the organizational justice perceived by the workers of a public university, hired under the outsourcing modality, and various demographic variables.

\section{Hypothesis}

H1: Workers hired by the university under the outsourcing modality perceive that the level of organizational justice is low.

$\mathrm{H} 2$ : The level of organizational justice perceived by the university workers hired under the outsourcing modality differs according to their age.

H3: The level of organizational justice perceived by university workers hired under the outsourcing modality is different according to the gender of the workers.

H4: The level of organizational justice perceived by university workers hired under the outsourcing modality is different according to their marital status.

H5: The level of organizational justice perceived by university workers hired under the outsourcing modality differs according to their seniority.
H6: The level of organizational justice perceived by university workers hired under the outsourcing modality is different according to the academic degree they hold.

\section{Methodology to be developed}

\section{Research type and design}

This is a descriptive research, non-experimental and cross-sectional type, carried out with a quantitative approach (Hernández-Sampieri \& Mendoza, 2018), using the survey as a data collection technique, which was virtually through of using a form.

\section{Characterization of the sample}

From a total of 20 workers from a public HEI located in the state of Tabasco, Mexico who are currently hired under the outsourcing modality, a non-probabilistic sample was obtained by convenience of 16 participants whose age ranges between 27 and 44 years of age, the average being 32 years.

Regarding gender, the equal participation between men and women stands out, since $50 \%$ was registered for each case. In turn, $56.2 \%$ of the personnel reported being single; $25 \%$ live in common law and $18.8 \%$ be married.

Regarding seniority, $56.3 \%$ of those surveyed report having an antiquity of 1 to 3 years; followed by $25 \%$ who are 4 to 5 years old; $12.5 \%$ are less than 1 year old and only $6.2 \%$ reported having more than 6 years. On the other hand, considering the academic degree, $50 \%$ of the participants have a bachelor's degree and the other $50 \%$ have a master's degree.

\section{Instrument}

The instrument used to measure the organizational justice perceived by the study subjects is the Niehoff and Moorman scale (1993) adapted by Patlán et al. (2014) for use with the Mexican population. This scale consists of 18 items that are measured through the Likert scale with 5 response options ranging from $1=$ totally disagree to $5=$ totally agree and considers three factors of organizational justice: 1) distributive justice, 2) justice procedural and 3) interactional justice. The operationalization of the study variables is presented in Table 2 . 


\begin{tabular}{|l|l|}
\hline Variable & Operational definition \\
\hline $\begin{array}{l}\text { Organizational } \\
\text { Justice }\end{array}$ & $\begin{array}{l}\text { Equal opportunities and results for } \\
\text { all workers in the organization. }\end{array}$ \\
\hline $\begin{array}{l}\text { Distributive } \\
\text { justice }\end{array}$ & $\begin{array}{l}\text { Equitable allocation of rewards, } \\
\text { incentives and sanctions to workers } \\
\text { in an organization. }\end{array}$ \\
\hline $\begin{array}{l}\text { Procedural } \\
\text { justice }\end{array}$ & $\begin{array}{l}\text { Fairness in the application of } \\
\text { procedures through which the } \\
\text { organization assigns resources, } \\
\text { benefits and other decisions to } \\
\text { workers. }\end{array}$ \\
\hline $\begin{array}{l}\text { Interactional } \\
\text { justice }\end{array}$ & $\begin{array}{l}\text { It refers to the perception of fair, } \\
\text { equitable and adequate treatment } \\
\text { that workers receive from their } \\
\text { superiors. }\end{array}$ \\
\hline
\end{tabular}

Table 2 Variables operationalization

Prepared based on Niehoff and Moorman (1993); Patlán et al. (2014) and Hernández, Martínez, Martínez, Castillo, and Corichi (2015).

\section{Análisis de datos}

For data analysis, the statistical program Statistical Package for the Social Sciences (SPSS) was used. The first analysis was the exploration of the database, in which the conditions of normality in the data, the missing values and the outliers were evaluated.

Subsequently, the descriptive statistics and the quartiles were analyzed as a numerical summary, to designate the level of organizational justice in general perceived by the participants, as well as the levels of justice for each of the dimensions that make up this construct.

In turn, the nonparametric U MannWhitney and Kurskal-Wallis tests were used to identify differences between independent groups with respect to the demographic variables under study (age, gender, marital status, seniority and academic degree).

\section{Results}

The statistical tests carried out allowed obtaining the following results.

\section{1) Normality analysis}

The Shapiro-Wilk test shows a level of significance greater than 0.05 for the Organizational Justice variable and for each of its dimensions, as seen in Table 3 and Figure 1, which indicates that the data fit a distribution normal.

\begin{tabular}{|l|r|r|r|}
\hline \multicolumn{1}{|c}{ Variable } & \multicolumn{1}{c}{ Statistical } & gl & \multicolumn{1}{c|}{ Sig. } \\
\hline Organizational justice & .95 & 16 & .52 \\
\hline Distributive justice & .95 & 16 & .45 \\
\hline Procedural justice & .96 & 16 & .63 \\
\hline Interactional justice & .94 & 16 & .39 \\
\hline
\end{tabular}

Table 3 Results of the normality test. Descriptive of the study variables

Own Elaboration

\section{2) Descriptive statistics}

According to the data seen in Table 4, it is observed that the workers hired by the HEI under study through the outsourcing modality, perceive average levels of organizational justice in the institution. In turn, the organizational justice factor with the highest mean is interactional justice with 3.69 , followed by procedural justice with 3.50 and the lowest mean was obtained by distributive justice with 3.09 .

On the other hand, according to the standard deviation, low levels of variability were identified in the data. In this sense, the most dispersed dimensions are distributive justice with 0.71 and interactional justice with 0.69 , while the most uniform dimension is procedural justice with 0.65 . In general, organizational justice registered a dispersion of 0.62 , which denotes low variation in the data.

\begin{tabular}{|l|r|r|}
\hline \multicolumn{1}{|c}{ Variable } & Mean & $\begin{array}{r}\text { Deviation } \\
\text { Standard }\end{array}$ \\
\hline Organizational justice & 3.50 & 0.62 \\
\hline Distributive justice & 3.09 & 0.71 \\
\hline Procedural justice & 3.50 & 0.65 \\
\hline Interactional justice & 3.69 & 0.69 \\
\hline
\end{tabular}

Table 4 Descriptive of the study variables Own Elaboration

\section{3) Level of perception of Organizational Justice}

In order to respond to $\mathrm{H} 1$, which indicates: workers hired by the university under the outsourcing modality perceive that the level of organizational justice is low, a quartile analysis was carried out, partially accepting this hypothesis, because according to the data presented Table 5 identifies a medium level of organizational justice, since $50 \%$ of the participants perceive that organizational justice oscillates between low and very low levels, while the other 50\% register high and very high levels of perception of organizational justice. 


\begin{tabular}{|l|r|c|c|}
\multicolumn{1}{|c}{ Level } & Percentile & \multicolumn{1}{c|}{ Rank } & $\%$ \\
\hline 1. Very low & 25 & $2.61-2.83$ & $25 \%$ \\
\hline 2. Low & 50 & $2.84-3.58$ & $25 \%$ \\
\hline 3. High & 75 & $3.59-3.93$ & $25 \%$ \\
\hline 4. Very high & 100 & $3.94-4.67$ & $25 \%$ \\
\hline
\end{tabular}

Table 5 Intensity scale to measure the level of perception of organizational justice Own Elaboration

\section{4) Relationship between organizational justice and various demographic variables}

Table 6 shows the results of the comparison tests between independent samples to respond to $\mathrm{H} 2$, $\mathrm{H} 3, \mathrm{H} 4, \mathrm{H} 5$ and H6, identifying that in the demographic variables: age, gender, marital status and seniority, no differences were found. statistically significant, which leads to retain the null hypothesis that maintains the non-existence of differences between the groups compared for each of these variables. Therefore, with a $95 \%$ confidence level it is not possible to accept $\mathrm{H} 2$, $\mathrm{H} 3, \mathrm{H} 4$ and $\mathrm{H} 5$.

\begin{tabular}{|c|c|c|c|}
\hline Variable & Sig. & Decision & Test \\
\hline Age & 0.15 & $\begin{array}{l}\text { Retain the null } \\
\text { hypothesis }\end{array}$ & $\begin{array}{l}\text { Kruskal- } \\
\text { Wallis }\end{array}$ \\
\hline Gender & 1.00 & $\begin{array}{l}\text { Retain the null } \\
\text { hypothesis }\end{array}$ & $\begin{array}{l}\text { U Mann- } \\
\text { Whitney }\end{array}$ \\
\hline Civil s & 0.11 & $\begin{array}{l}\text { Retain the null } \\
\text { hypothesis }\end{array}$ & $\begin{array}{l}\text { Kruskal- } \\
\text { Wallis }\end{array}$ \\
\hline Antic & 0.52 & $\begin{array}{l}\text { Retain the null } \\
\text { hypothesis }\end{array}$ & $\begin{array}{l}\text { Kruskal- } \\
\text { Wallis }\end{array}$ \\
\hline $\begin{array}{l}\text { Academic } \\
\text { degree }\end{array}$ & 0.01 & $\begin{array}{l}\text { Reject the null } \\
\text { hypothesis }\end{array}$ & $\begin{array}{l}\text { Kruskal- } \\
\text { Wallis }\end{array}$ \\
\hline
\end{tabular}

Table 6 Comparison tests between independent groups. Asymptotic significances are shown. Significance level is 0.05

Own Elaboration

For its part, regarding the academic degree variable, the Kruskal-Wallis test obtained a significance value of 0.01 , which is below the $\mathrm{P}$ value $=0.05$. Therefore, with a 95\% confidence level, there is enough evidence to reject the null hypothesis that maintains the nonexistence of differences regarding the academic grade of the workers and their level of perception of organizational justice, as well as to accept H6, That points:

The level of organizational justice perceived by university workers hired under the outsourcing modality is different according to the academic degree they hold.

\section{Conclusions}

In this research, it was identified that the level of organizational justice perceived by the workers hired by the HEI under study under the outsourcing modality is medium. The dimension with the greatest presence is interactional justice, followed by procedural justice and the least perceived is distributive justice.

These findings indicate that workers perceive that their bosses give them fair, equitable and adequate treatment; that there is equity in the procedures established for work assignments and other resources; However, the participating HEI needs to improve its efforts so that the proportion of workers who perceive low levels of organizational justice, particularly with regard to distributive justice (distribution of rewards and sanctions, tasks and responsibilities by their bosses), improve their attitudes and behaviors towards work.

Likewise, when analyzing different demographic variables such as: age, gender, marital status, seniority, academic degree and their relationship with the level of organizational justice perceived by the workers in the sample, it was only corroborated that the academic degree that the workers hold is a differentiating factor.

This finding may be related to the fact that the more academic preparation workers have, the higher job expectations they have in relation to the benefits provided by the organization in which they perform their duties.

However, future research suggests analyzing in greater detail what could be the causes associated with the level of perception of organizational justice and the academic degrees held by the collaborators. Likewise, it is recommended to carry out similar studies with larger populations that allow greater generalization of the results obtained.

\section{References}

Al-Zu'bi, H. (2010). A Study of Relationship between Organizational Justice and Job Satisfaction. International Journal of Business and Management, 5(12). https://doi.org/10.5539/ijbm.v5n12p102 
Albanesi, R. (2015). Historia reciente del trabajo y los trabajadores. Apuntes sobre lo tradicional y lo nuevo, lo que cambia y permanece en el mundo del trabajo. Trabajo y Sociedad, unknown (25), 387-403.

Castillo, C., \& Fernandez, V. (2017). Relationships between the dimensions of organizational justice and students' satisfaction in university contexts. Intangible Capital, 13, 282-301. https://doi.org/10.3926/ic.774

Cernas, D., Mercado, P., \& León, F. (2016). Job satisfaction and organizational commitment: Test of measurement equivalence between Mexico and the United States. Contaduría y Administración, $\quad 63(2), \quad 18$. http://www.scielo.org.mx/pdf/cya/v63n2/01861042-cya-63-02-00006-en.pdf

Cernas, D., Salgado, P., \& León, F. (2018). Satisfaccion laboral y compromiso organizacional. Contaduria y Administracion, 63(2), 1-23.

Charaja, Y., \& Mamani, J. (2014). Satisfacción Laboral y Motivación de los Trabajadores de la Dirección Regional de Comercio Exterior y Turismo-Puno-Perú, 2013. Comunic@cción, 1(1), 5-13. http://www.scielo.org.pe/pdf/comunica/v5n1/a0 $1 v 5 n 1 . p d f$

Chiang, M., Salazar, C., \& Núñez, A. (2007). Clima organizacional y satisfacción laboral en un establecimiento de salud estatal: hospital tipo 1. Theoria-Revista de Teoria Historia y Fundamentos de La Ciencia, 16(2), 61-76.

Claure, M., \& Böhrt, M. (2015). Tres dimensiones del compromiso organizacional: identificación, membresía y lealtad. Ајауu Órgano de Difusión Científica Del Departamento de Psicología UCBSP, 1991, 7. http://www.scielo.org.bo/scielo.php?pid=S2077 $-21612004000100008 \&$ script=sci_abstract

Colquitt, J. (2001). On the Dimensionality of Organizational Justice: A Construct Validation of a Measure. Journal of Applied Psychology, 6, 4. https://doi.org/10.1037/0021-9010.86.3.386
Cropanzano, R., Bowen, D., \& Gilliland, S. (2007). The management of organizational justice. Academy of Management Perspectives, 21(4), 34-48. https://doi.org/10.5465/AMP.2007.27895338

Dieterlen, P. (2014). Justicia Distributiva, pobreza y género. Open Insigh, 8, 39-59. https://doi.org/ISSN: 2007-2406 39

Echaiz, D. (2008). EL CONTRATO DE OUTSOURCING. Boletín Mexicano de Derecho Comparado, 122, 763-793. http://www.scielo.org.mx/pdf/bmdc/v41n122/v 41n122a6.pdf

Fox, S., Spector, P., \& Miles, D. (2001). Counterproductive Work Behavior (CWB) in Response to Job Stressors and Organizational Justice: Some Mediator and Moderator Tests for Autonomy and Emotions. Journal of Vocational Behavior, 59, 291-309. https://doi.org/10.1006/jvbe.2001.1803

García, M., \& Forero, C. (2014). Cambio organizacional y percepción de la justicia organizacional en una entidad de la ciudad de Bogotá-Colombia. Diversitas, 10(2), 293. https://doi.org/10.15332/s1794-

9998.2014.0002.07

Greenberg, J. (1993). The Social Side of Fairness: Interpersonal and Informational Classes of Organisational Justice. Justice in the Workplace: Approaching Fairness in Human Resource Management, 4, 79-103.

Hernández-Sampieri, R., \& Mendoza, C. (2018). Metodología de la Investigación:Las rutas cuantitativa, cualitativa y mixta. Ciudad de México: Mc Graw Hill.

Hernández, T., Martínez, E., Martínez, E., Castillo, F., \& Corichi, A. (2015). Justicia Organizacional Y Su Relación Con El Personal Docente De Una Institución De Educación Superior. Global Journal of Management and Business Research, 15(2), 32-42. Retrieved from

https://www.semanticscholar.org/paper/Justicia -Organizacional-Y-Su-Relacion-Con-El-DeUna-Gracia-

Torres/6cb9cba36de50f63c162da7453a192875f $136 \mathrm{c} 30$ 
Jordan, J. S., \& Turner, B. A. (2008). The feasibility of single-item measures for organizational justice. Measurement in Physical Education and Exercise Science, 12(4), 237257.

https://doi.org/10.1080/10913670802349790

Kozlowski, S. (2012). The Oxford Handbook of Organizational Psychology. In The Oxford Handbook of Organizational Psychology (Vol. 1, Issue February). https://doi.org/10.1093/oxfordhb/97801999283 09.001 .0001

Lockward, D., \& Ailín, M. (2011). El rol de la confianza en las organizaciones a través de los distintos enfoques o pensamientos de la administración. Ciencia y Sociedad, XXXVI(3), 464-502.

http://www.redalyc.org/articulo.oa?id=8702252 6005

Manriquez, M. R., Rendón, L. P., SánchezFernández, M. D., \& Guerra, J. F. (2017). Estrategias de compensación y su relación con el Compromiso Organizacional en los docentes de las Instituciones de Educación Superior en México. Revista Ibero-Americana de Estratégia, 16(02), 90-103.

https://doi.org/10.5585/riae.v16i2.2455

Marsollier, R., \& Aparicio, M. (2011). El bienestar psicológico en el trabajo y su vinculación con el afrontamiento en situaciones conflictivas. Psicoperspectivas, 10(1), 209-220. https://doi.org/10.2225/PSICOPERSPECTIVA S-VOL10-ISSUE1-FULLTEXT-10

Martínez-Tur, V., Moliner, C., Ramos, J., Luque, O., \& Gracia, E. (2014). Calidad y Bienestar en Organizaciones de Servicios: El Papel del Clima de Servicio y La Justicia Organizacional (Vol. 35, Issue 2). http://www.papelesdelpsicologo.esl

Mladinic, A., \& Isla, P. (2011). Justicia Organizacional: Entendiendo la Equidad en las Organizaciones. Psykhe, 11(2). http://www.psykhe.cl/index.php/psykhe/article/ view/428

Niehoff, B., \& Moorman, R. (1993). Justice As a Mediator of the Relationship Between Methods of Monitoring and Organizational Citizenship Behavior. Academy of Management Journal, 36(3), $527-556$. https://doi.org/10.2307/256591
Omar, A. (2004). Justicia organizacional, individualismo-colectivismo y estrés laboral. 17(July 2014), 261-267.

Omar, A. (2006). Justicia organizacional, individualismo-colectivismo y estrés laboral. 16(2), 207-217. https://doi.org/1405-1109

Omar, A. (2018). Psychometric properties of Colquitt's Organizational Justice Scale in Argentine workers. Liberabit. Revista Peruana de Psicología, 24(1), 61-79. https://doi.org/10.24265/liberabit.2018.v24n1.0 5

Patlán-Pérez, J., \& Martínez, E. (2012). El clima y la justicia organizacional y su efecto en la satisfacción laboral. Revista Internacional Administración \& Finanzas, 5(5), 1-20.

Patlán, J. (2016). Derechos laborales: una mirada al derecho a la calidad de vida en el trabajo. Ciencia Ergo Sum, 23(2). https://www.redalyc.org/jatsRepo/104/1044609 4004/html/index.html

Patlán, J., Flores, R., Martínez, E., \& Hernández, R. (2014). Validez y confiabilidad de la escala de justicia organizacional de Niehoff y Moorman en población mexicana. Contaduría y Administración, 59(2), 97-120. https://doi.org/10.1016/S0186-1042(14)712562

Peña-Ochoa, M., \& Durán, N. (2016). Justicia Organizacional, Desempeño Laboral y Discapacidad. Rev.Colomb.Cienc.Soc., 7(1), 201-222. http://orcid.org/0000-0002-1825-0097

Quezada-Abad, C. (2017). Percepción de la justicia organizacional de los empleados de la Universidad Técnica de Machala. Ciencia Unemi, 10(23), 70. https://doi.org/10.29076/issn.25287737vol10iss23.2017pp70-79p

Rahim, A., Magner, N., \& Shapiro, D. (2000). Do justice perceptions influence styles of handling conflict with supervisors?: What justice perceptions, precisely? International Journal of Conflict Management, 11(1), 9-31. https://doi.org/10.1108/eb022833 
Ríos, L., \& Carranza, G. (2019). Determinantes de explicación del constructo justicia organizacional y su impacto con satisfacción y desempeño laborales. NovaRUA, 10(17), 37-50. https://doi.org/10.20983/novarua.2018.17.3

Rodrigues, L., Santos, C., \& Roazzi, A. (2009). Justiça distributiva: Uma revisão da literatura psicossocial e desenvolvimentista. Psicologia Em Estudo, 14(4), 631-640. https://doi.org/10.1590/S141373722009000400003

Rodríguez-Montalbán, R., Martínez-Lugo, M., \& Sánchez-Cardona, I. (2015). Análisis de las Propiedades Psicométricas de la Escala de Justicia Organizacional de Colquitt en una Muestra de empleados(as) en Puerto Rico. Revista Puertorriqueña de Psicología, 26(2), 270-286.

http://www.redalyc.org/articulo.oa?id=2332456 21009

Rodríguez, R., Martínez, M., \& Salanova, M. (2014). Justicia organizacional, engagement en el trabajo y comportamientos de ciudadanía organizacional: Una combinación ganadora. Universitas Psychologica, 13(3). https://doi.org/10.11144/javeriana.upsy13-

3.joet

Rubio, L. (2018). Justicia organizacional y engagement en docentes de una universidad privada de Armenia, Quindío. Contexto, 7, 4756. https://doi.org/10.18634/ctxj.7v.0i.884

Sánchez, M., \& García, M. D. L. (2017). Satisfacción laboral en los entornos de trabajo. Una exploración cualitativa para su estudio. Scientia et Technica, 22(2), 161-166. http://www.redalyc.org/pdf/849/84953103007.p df

Smith, A. (1976). An Inquiry into the Nature and Causes of the Wealth of Nations (London:). London : printed for W. Strahan; and T. Cadell, 1776. http://hdl.handle.net/1842/1455

Sztulwark, S., \& Míguez, P. (2012). Conocimiento y valorización en el nuevo capitalismo. Realidad Económica, 11-32.
Tziner, A., Felea, M., \& Vasiliu, C. (2015). Relating ethical climate, organizational justice perceptions, and leader-member exchange (LMX) in Romanian organizations. Revista de Psicologia Del Trabajo y de Las Organizaciones, $31(1), \quad 51-57$. https://doi.org/10.1016/j.rpto.2015.02.005

Vesga, J. (2011). Los tipos de contratación laboral $\mathrm{y}$ sus implicaciones en el contrato psicológico. Pensamiento Psicológico, 9(16), 171-182. Retrieved from https://www.semanticscholar.org/paper/Justicia -Organizacional-Y-Su-Relacion-Con-El-De-

Una-Gracia-

Torres/6cb9cba36de50f63c162da7453a192875f $136 \mathrm{c} 30$

Zúñiga-Fajuri, A. (2011). Teorías de la justicia distributiva: una fundamentación moral del derecho a la protección de la salud. 55. 